\title{
THE EFFECT OF MACRO FACTORS ON BANK CREDIT ACTIVITY IN THE REPUBLIC OF SERBIA
}

\author{
Dejan Živkov* \\ Novi Sad School of Business, Novi Sad, Republic of Serbia \\ Simo Poparić \\ Erste Bank, Novi Sad, Republic of Serbia \\ Miloš Ilić \\ Erste Bank, Novi Sad, Republic of Serbia
}

\begin{abstract}
This paper investigates whether and how key macro-fundamentals in Serbia affect the volumes of issued loans of Erste bank to public and business sector in Serbia. We made an effort to determine which particular macro factor has the highest influence on issued credits of Erste bank, and to measure the exact average magnitude of these influences. The main idea is to find out how GDP, inflation, central bank referent interest rate, exchange rate changes and Euribor affect short-term and long-term credit activity of Erste bank in Serbia. The computations are done by applying several multivariate regression models in which dependant variables are the volume of issued credits towards civil sector and enterprises. Based on the results, we can report that Euribor is the most important factor of all scrutinized macro-aggregates, since it affects most of the analysed bank loans. Besides Euribor, we find that other macro fundamentals influence the issued loans only sporadically. In other words, the level of GDP and inflation affect only long-term loans for businesses, while referent interest rate influences only short-term loans for public. We find that exchange rate changes have no effect on any loan of Erste bank, whatsoever, which clearly indicates that the bank protects itself very successfully against this type of macro risk.
\end{abstract}

Key words: Erste bank, macroeconomic factors, short-term and long-term loans, multivariate linear regression models, public sector and enterprises

JEL classification: C22, G21, F62

\footnotetext{
*dejanzivkov@gmail.com
} 


\title{
EFEKAT MAKROFAKTORA NA KREDITNU AKTIVNOST BANKE U REPUBLICI SRBIJI
}

\begin{abstract}
Sažetak: Ovaj rad istražuje da li i kako ključni makrofundamenti u Srbiji utiču na količinu izdatih kredita Erste banke građanima i preduzećima u Srbiji. Težnja autora se odnosi na utvrđivanje određenog makrofaktora koji ima najveći uticaj na izdate kredite Erste banke, kao i na merenje tačne prosečne veličine ovih uticaja. Cilj rada je da se otkrije kako BDP, inflacija, referentna kamatna stopa Narodne banke Srbije, promene kursa $i$ Euribor utiču na kratkoročnu $i$ dugoročnu kreditnu aktivnost Erste banke $u$ Srbiji. Izračunavanje se vrši primenom nekoliko multivarijantnih regresijskih modela $u$ kojima su zavisne varijable obimi kredita odobrenih stanovništvu i privredi. Na bazi rezultata možemo zaključiti da je Euribor najvažniji faktor svih pregledanih makroagregata, jer utiče na većinu analiziranih bankarskih kredita. Pored Euribora, otkrivamo da drugi makrofundamenti utiču na izdate kredite samo sporadično. Drugim rečima, nivo BDP-a i inflacija utiču samo na dugoročne kredite za preduzeća, dok referentna kamatna stopa utiče samo na kratkoročne kredite za stanovništvo. Otkrivamo da promene kursa nemaju uticaja ni na jedan kredit Erste banke, što jasno ukazuje da se banka veoma uspešno štiti od ove vrste makrorizika.
\end{abstract}

Ključne reči: Erste banka, makroekonomski faktori, kratkoročni i dugoročni krediti, multivarijantni linearni regresioni modeli, civilni sektor i preduzeća

\section{INTRODUCTION}

Various financial intermediaries, such as investment companies, mutual funds, insurance companies and particularly banks, play a crucial role in development of economy and their prosperity is important for an overall macroeconomic stability (see e.g. Lojanica and Tubić-Ćurčić, 2019). Hasanov, Bayramli and AlMusehel (2018) asserted that global trends show that the share of the banking sector in the financial system has increased in recent decades. Ongore (2013) contended that commercial banks play a vital role in the economic resource allocation and contribute to country's economic growth by making funds available for investors to borrow. However, their performance can be impacted by different internal and external factors which can be classified into bank specific (internal) and macroeconomic variables, as Ongore (2013) pointed out. The internal factors are individual, bank-specific characteristics which are basically related to the internal decisions made by management and board. The external factors are more important and have more profound impact on banks, because they can influence whole sectors or an entire country, and as such they are beyond the control of any bank and can inflict serious problems on bank 
businesses (see e.g. Kamani, 2019; Lee, Lin, Lin and Zhao, 2020; Ognjanović and Pešterac, 2019).

Based on the aforementioned, this paper tries to find out how five key macroeconomic factors - GDP, inflation, central bank referent interest rate, exchange rate changes and Euribor, affect short-term and long-term credit activity of Erste bank in the Republic of Serbia, which are issued to civil population and enterprises. To the best of authors' knowledge, this is the first time that a paper does this type of investigation, using data from a commercial bank in Serbia, and we strongly believe that it will contribute to the existing literature. The aim of this study is to econometrically determine which particular macro factors have the highest influence on credit activity of Erste bank, and to measure the exact average magnitude of these influences. In addition, the goal is to provide a reasonable and economically-based explanation for every highly statistically significant factor impacting the volume of the bank loanable funds. With this kind of knowledge, managing structures of Erste bank could define their credit strategies towards the bank's clients and also could devise various plans to mitigate looming risks that might strike the bank businesses. The methodology used for this research involves several multivariate regression models, in which independent variables are short-term and long-term loans granted to public sector and enterprises. On the other hand, in every multivariate model, independent variables are macroeconomic variables that are listed above. We have chosen research methodology referring to the following recent papers, which used multivariate linear regression models in their papers - Chen, Pourahmadi and Maadooliat (2014), Mori and Suzuki (2018), Xia, Zhang, Wang and Yeh (2019), Petrella and Raponi (2019).

Beside introduction, the rest of the paper is structured as follows. The second section presents brief literature review. The third section explains used methodology and dataset. Section four contains estimated results and provides explanations. The last section gives concluding remarks.

\section{BRIEF LITERATURE REVIEW}

Many theoretical researchers have investigated how different macroeconomic fundamentals affect banks' businesses. For instance, Baum, Caglayan and Ozka (2009) examined the effects of uncertainty on the allocation of banks' scarce resources in the U.S. and claimed that the stability of the macroeconomic environment will favour more efficient allocation of loanable funds. They demonstrated that macroeconomic uncertainty (measured by the volatility of GDP growth or inflation) has a negative effect on the cross-sectional dispersion of total loans-to-assets ratio. Glen and Mondragón-Vélez (2011) studied the effects of business cycles on the performance of commercial bank loan 
portfolios. They covered major developing economies in the period 1996-2008 and gauged loan performance via loan loss provisions. They found that economic growth is the main driver of loan portfolio performance, whereas interest rates have second-order effect. In addition, their results indicated that the relationship between loan loss provisions and economic growth is highly non-linear only under extreme economic stress. Gu, Xin and $\mathrm{Xu}$ (2019) investigated whether the stock price crash risk is priced in private debt contracting in China. They disclosed that the expected stock price crash risk is positively associated with the bank loan interest spread, which indicates that banks regard stock price crashes in China as an important risk factor when issuing loans.

Caglayan and $\mathrm{Xu}$ (2019) used a large panel of commercial bank data gathered from 15 countries and looked at the distortionary effects of inflation volatility on the allocation of bank loans. They asserted that inflation volatility would force bank managers to behave more conservatively in issuing new loans. In contrast, when inflation volatility is low, bank managers have space to lend in more idiosyncratic fashion. They concluded that a strong negative relation exists between inflation volatility and the dispersion of loans-to-assets ratio. The study of Abuka, Alinda, Minoiu, Peydró and Presbitero, (2019) researched Uganda's volume of loan application, taking into account unanticipated variation in monetary policy. They showed that monetary contraction reduces credit supply of banks, which is mirrored in increasing rate of loan application rejections, which is especially true for banks with more leverage and sovereign debt exposure. Orzechowski (2017) researched the long-run nexus between bank profits, loan growth, and monetary policy at different types of profitable banks in the U.S. He reported that monetary policy has a slightly larger negative relationship with real estate loans in banks with above average profits than with their less profitable peers. He also contended that commercial loan growth in low-profit banks may be more sensitive to their loan loss provisions than to monetary policy. His overall conclusion is that loan portfolio ratio shows a significant negative relationship with monetary policy and a positive relationship with provisions.

\section{RESEARCH METHODOLOGY AND DATASET}

This paper uses annual data, covering the period from 2005-2018. In order to estimate the extent to which the selected macroeconomic factors (gross domestic product, inflation, exchange rate, referent interest rate and Euribor) affect the volume of loans of Erste bank, issued to civil population and enterprises in short and long-term in Serbia, we use several multivariate linear 
regression models. In these models, dependent variables are the volume of issued loans to population and economy, whereas the independent variables are the selected macroeconomic aggregates. For comparability of results and consistency in modelling, we set all independent variables as rates i.e. for those variables that were not empirically given in rates. Table 1 presents descriptive statistics for the independent variables. On the other hand, dependent variables are omitted from Table 1, since they are observed in absolute values (in billions of Republic of Serbia dinars - RSD), not rates, which means that they do not follow normal distribution. In order to provide an insight into the relative value of the issued loans, we show their yearly dynamics in Figure 1.

Table 1

Descriptive statistics for the independent variables

\begin{tabular}{|l|l|l|l|l|c|}
\hline & Mean & S.D. & Skewness & Kurtosis & JB \\
\hline GDP & 2.820 & 3.417 & 0.338 & 2.831 & 0.283 \\
\hline Inflation & 6.910 & 4.685 & 0.377 & 2.127 & 0.777 \\
\hline Referent interest rate & 7.648 & 2.786 & -0.478 & 2.008 & 1.107 \\
\hline Exchange rate changes & 3.080 & 5.746 & -0.106 & 2.033 & 0.572 \\
\hline Euribor & 0.899 & 1.483 & 1.017 & 2.485 & 2.566 \\
\hline
\end{tabular}

Note. Authors' calculation.

Legend: S.D. is an abbreviation for standard deviations; JB stands for Jarque-Berra coefficient of normality.

According to Table 1, average annual GDP growth in the observed period is $2.8 \%$, average annual inflation is relatively high, amounting to $6.9 \%$, whereas average annual referent interest rate is also high with the value of $7.6 \%$. Annual average depreciation of RSD is 3\%, and Euribor has relatively low average annual value of $0.899 \%$. The variable with the highest volatility is GDP, which is followed by inflation. All macro-variables have low skewness and kurtosis, which suggest that these variables have normal distribution. This is confirmed by JB coefficient of normality.

Equations 1-4 present linear model specifications for four independent variables:

$$
\begin{aligned}
& L T L E_{t}=C+\alpha_{1} G D P_{t}+\alpha_{2} I N F_{t}+\alpha_{3} R I R_{t}+\alpha_{4} E R C_{t}+\alpha_{5} E U R_{t}+\varepsilon_{t} \\
& L T L P_{t}=C+\alpha_{1} G D P_{t}+\alpha_{2} I N F_{t}+\alpha_{3} R I R_{t}+\alpha_{4} E R C_{t}+\alpha_{5} E U R_{t}+\varepsilon_{t} \\
& S_{T L E_{t}}=C+\alpha_{1} G D P_{t}+\alpha_{2} I N F_{t}+\alpha_{3} R I R_{t}+\alpha_{4} E R C_{t}+\alpha_{5} E U R_{t}+\varepsilon_{t} \\
& S_{L L P_{t}}=C+\alpha_{1} G D P_{t}+\alpha_{2} I N F_{t}+\alpha_{3} R I R_{t}+\alpha_{4} E R C_{t}+\alpha_{5} E U R_{t}+\varepsilon_{t}
\end{aligned}
$$



SERBIA

where acronyms LTLE, LTLP, STLE and STLE denote long-term loans for enterprises, long-term loans for population, short-term loans for enterprises and short-term loans for population, respectively. As for independent variables, $G D P$ is gross domestic product, $I N F$ is rate of inflation, $R I R$ stands for referent interest rate, $E R C$ labels exchange rate changes and $E U R$ is European interbank rate - Euribor. $C$ is constant, and $\varepsilon_{t}$ is white noise error term that follows Gaussian (normal) distribution, $\varepsilon_{t} \sim N\left(0, \sigma^{2}\right)$, with zero mean and variance.

The research was conducted on annual data that ranges from 2005-2018. We are unable to use higher frequency data for computations, because issued data for loans are available only in gross amount for one year. The data for bank loans was collected from the financial reports of Erste bank. Empirical data for macro-factors were collected from the official website of National bank of Serbia.
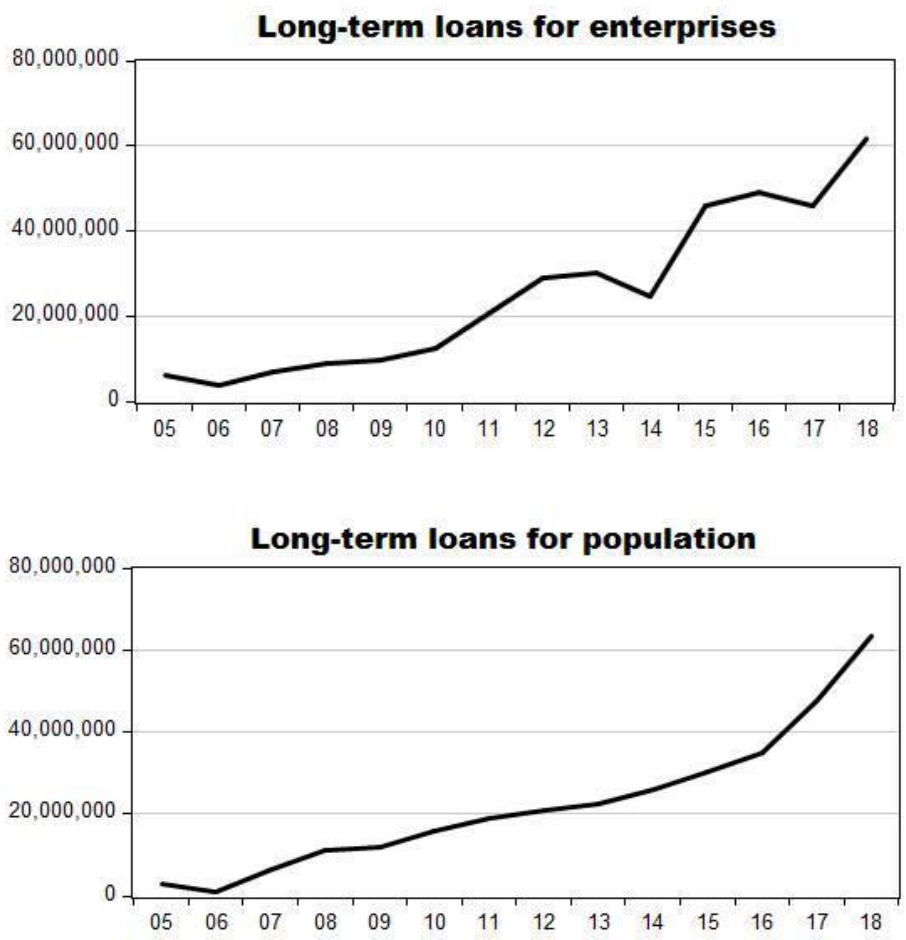

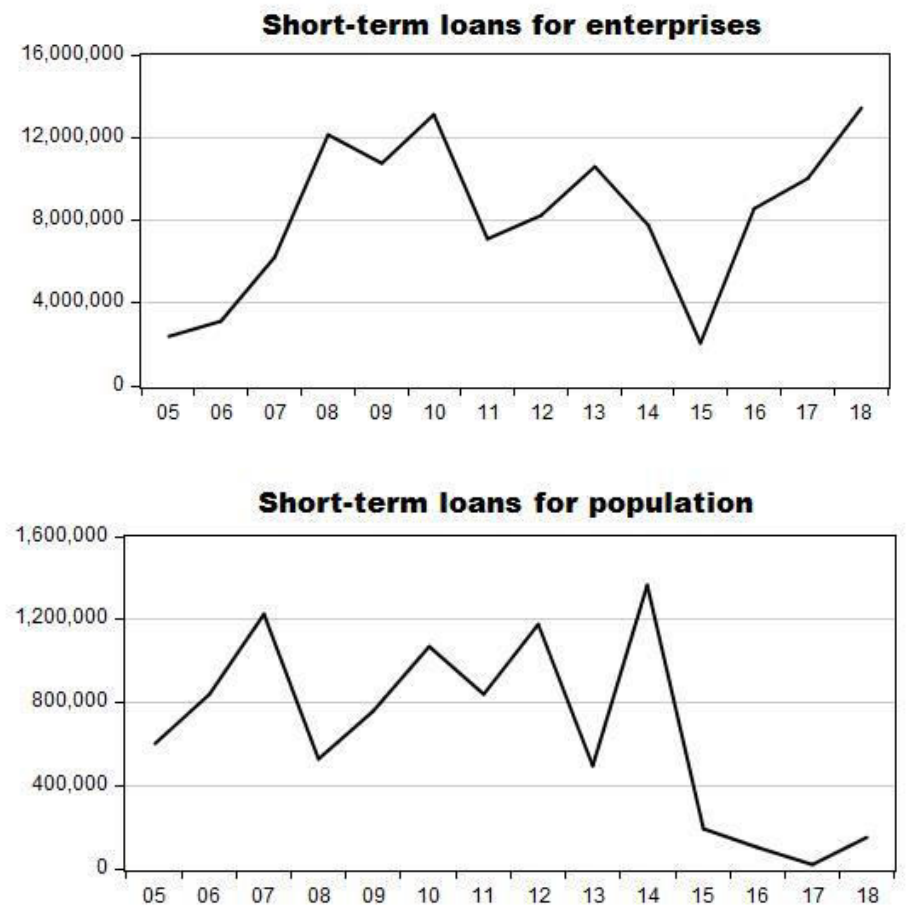

Figure 1. Dynamics of issued loans in thousands of RSD Note. Authors' calculation.

\section{RESEARCH RESULTS}

This section presents the results of the estimated multivariate models, and the results are summarized in Table 2. Since dependent variables are inserted in the models in billions of RSD, the estimated parameters are also expressed in billions of RSD. In other words, we measure how the change of independent macro-factors affects volumes of issued loans in billions of RSD of Erste bank. In the following subsections, we interpret estimated parameters and give viable and economically-based explanations. 
46 | THE EFFECT OF MACRO FACTORS ON BANK CREDIT ACTIVITY IN THE REPUBLIC OF SERBIA

Table 2

Estimated parameters

\begin{tabular}{|l|c|c|c|c|c|}
\hline \multirow{2}{*}{$\begin{array}{c}\text { Independent } \\
\text { variables }\end{array}$} & $\begin{array}{c}\text { Parameter } \\
\text { Estimates }\end{array}$ & LTLE & LTLP & STLE & STLP \\
\cline { 2 - 6 } & \multicolumn{5}{|c|}{} \\
\hline \hline Panel A. Estimated parameters & $\alpha_{1}$ & $2.3^{* *}$ & 1.4 & -0.1 & -0.04 \\
\hline GDP & $\alpha_{2}$ & $-1.5^{*}$ & -1.1 & -0.1 & -0.04 \\
\hline Inflation & $\alpha_{3}$ & 0.9 & -1.7 & 0.002 & $-0.1^{* * *}$ \\
\hline Referent interest rate & $\alpha_{4}$ & 0.5 & -0.3 & 0.2 & 0.005 \\
\hline Exchange rate changes & $\alpha_{5}$ & $-9.6^{* * *}$ & $-7.5^{* * *}$ & -0.5 & $0.2^{* *}$ \\
\hline Euribor & & & & 0.82 \\
\hline \hline Panel B. Diagnostic tests & 0.93 & 0.84 & 0.26 & 2.62 \\
\hline Determination coefficient $-\mathrm{R}^{2}$ & 1.82 & 2.07 & 1.98 & 0.190 \\
\hline Durbin-Watson test & 0.258 & 0.229 & 0.355 & \\
\hline Breusch-Godfrey test (p-value) & &
\end{tabular}

Note. Authors' calculation.

$* * *, * *, *$ represent statistical significance at $1 \%, 5 \%$ and $10 \%$ level, respectively.

\subsection{LONG-TERM LOANS FOR ENTERPRISES}

Generally, long-term loans are used by business entities when they want to finance fixed or current assets, to refinance existing loans or investments from their own funds. In particular, these loans are primarily used for the procurement of equipment and capacity expansion, the purchase of current working capital, the purchase of another legal entity, etc. Long-term loans are approved with a repayment period of more than 60 months.

According to Table 2, the following variables are found to be statistically significant in model for LTLE - GDP, inflation and Euribor. It can be seen that Euribor is a highly statistically significant parameter with probability of over $99 \%$, inflation is statistically significant up to $90 \%$ probability, while the impact of GDP on long-term corporate loans is statistically significant at a probability of over $95 \%$. In other words, estimated model for LTLE suggests that $1 \%$ of GDP growth affects the increase of long-term credit placements to enterprises in Serbia by RSD 2.33 billion. This estimate is in line with economic logic, 
because GDP growth implies an increase in industrial production, which is followed by an increase in investments, and this entails the need for financial resources, which are subsequently acquired from banks. Our results for GDP are well supported by the findings in the study of Mondragón-Vélez (2011).

Full value of inflation coefficient is $-1,487,271$, which means that $1 \%$ increase in inflation annually reduces long-term loans to enterprises by almost 1.5 billion of RSD. This is in line with expectations, since rising inflation negatively affects the activity of economic entities, spurs uncertainty in business forecasts, affects cost growth, and as a consequence, reduces overall revenues. Our findings for inflation coincide very well with the study of Caglayan and $\mathrm{Xu}$ (2019). In addition, we find that parameter for Euribor is $-9,608,748$, which is the largest of all statistically significant parameters in model for LTLE. This highly statistically significant coefficient means that Euribor exerts the greatest influence on long-term corporate loans in comparison with all the other independent variables in the system. In other words, a $1 \%$ rise in Euribor impacts the decline of long-term loans to the economy by more than 9.5 billion of RSD. The estimation of the parameters in front of Euribor is in line with expectations, because we observe long-term loans to companies are approved in euros. In other words, in order to issue these loans to the economy, Erste bank has to obtain these funds in the European interbank market and any increase in interest rates in that market reduces the volumes of issued loans towards Serbian companies, because the cost of long-term funds rises.

Referent interest rate and the exchange rate are not statistically significant for several reasons. First, the reference interest rate affects the price of loans granted by NBS to commercial banks, but in RSD, and since the dependent variable is long-term loans to enterprises expressed in euros, then it is logical that the change in the reference interest rate will have no effect on foreign currency loans. The exchange rate is also considered statistically insignificant, and the economic rationale behind this could be that long-term foreign currency loans to companies have a safeguard clause for the exchange rate changes. This means that the change in RSD/EUR does not pose a direct risk to the bank i.e., it does not play a significant role in the level of approved loans to the economy. This is because loans that are given in euros have to be returned in euros. The bank as a lender may has potential problems with the exchange rate increase in terms of clients' inability to repay the loan with the foreign currency clause to the bank, because non-export-oriented companies earn their income in RSD. Then the depreciation of exchange rate increases the cost of loan repayment that has a currency clause. However, speaking in average values, we did not find that exchange rate changes affect the volume of issued loans to Serbian enterprises. 
As for model adequacy, we refer to Živkov, Njegić and Ljumović (2013) and check for the presence of serial correlation by using two tests - Durbin-Watson (DW) and Breusch-Godfrey (BG). The value of Durbin-Watson tests is around 2, which indicates the absence of autocorrelation. In order to further support DW statistics, we calculated additional Breusch-Godfrey test, in which p-value also confirms that the model has no problem with autocorrelation. Coefficient of determination is very high and amounts to 93\%, which indicates that independent variables explain the dependent variable (LTLE) in 93\% in the multivariate regression model. This is very high percentage, which means that the choice of the independent variables is good.

\subsection{LONG-TERM LOANS FOR POPULATION}

When it comes to long-term loans for households and civil population, the dominant share are mortgages. These loans are granted in foreign currency or in $\mathrm{RSD}$, but when they are issued in RSD, they are hedged by a foreign currency clause, as in the case of LTLE, which protects the bank against possible exchange rate risks.

According to Table 2, the only parameter that is statistically significant is Euribor. Its statistical significance is very high and amounts to almost $98 \%$. Also, this parameter has a value of 7.46 billion, which means that a rise of $1 \%$ in Euribor in the European interbank foreign exchange market causes a decrease in long-term retail placements by almost 7.5 billion on average. This value is in line with economic logic because any increase in interest rate in the European interbank market is directly reflected in the increase in domestic loans to households and population (see Den Haan, Sumner \& Yamashiro, 2007; Busch and Prieto, 2014). Unlike the model from the previous subsection, in which the estimated Euribor parameter was -9.6 billion, this parameter is -7.5 billion, which suggests that the increase in Euribor by $1 \%$ has a more negative influence on LTLE than on LTLP. This discrepancy is expected, because the volume of loans to the economy in absolute numbers is higher than to the population.

Contrary to Euribor, all other variables are not statistically significant. In other words, this means that the percentage change in GDP does not affect the volume of long-term loans to households. According to the model, the percentage change in GDP is not large enough to stimulate an increase in the volume of long-term loans to households. Unlike long-term loans to households, the parameter in front of GDP in previous section is estimated as statistically significant. As we have stated, GDP growth influences the increase in volumes of issued credits to the economy because GDP growth itself implies growth of 
economic activity, export and industrial production. On the other hand, there is no direct link between GDP and retail lending towards civil population, as the model has shown.

The same is true for inflation, the reference interest rate and the exchange changes. According to Table 2, this means that inflation in Serbia was not high enough to cause the reduction of LTLP. This result is consistent with the LTLE finding, which has indicated that inflation does not have effect on long-term loans to enterprises. The referent interest rate is also assessed as insignificant, which is in line with expectations, since the reference interest rate defines the dinar borrowing price. In other words, due to the fact that LTLP are issued either in foreign currency or in RSD with a safeguard clause, the reference interest rate, most likely, will not be statistically significant. In addition, exchange rate changes are also statistically insignificant, which suggests that the change in the RSD/EUR has no effect on the amount of long-term loans towards households. The explanation is the same as in the case of LTLE i.e., long-term loans to households are protected by a foreign currency clause against possible changes in the exchange rate, hence the model does not find any effect of exchange rate on LTLP.

As in the previous model, DW and BG tests confirm that model does not have a problem with autocorrelation, while relatively high value of $R^{2}$ coefficient $(0.82 \%)$ suggests that independent variables explain LTLP in relatively high degree.

\subsection{SHORT-TERM LOANS FOR ENTREPRISES}

Short-term corporate loans are approved for financing current liquidity (current problem of payments to suppliers, payment of earnings, etc.), working capital, exports, refinancing of liabilities and loans to other banks and for other purposes. These loans are approved in RSD with foreign currency clause or in foreign currency. These loans have a repayment period of up to 12 months. According to Table 2, none of the estimated parameters in STLE model are statistically significant. A rational explanation behind these results would be that short-term corporate loans are mostly granted for the purpose of overcoming short-term illiquidity of economic entities. Given that all observed independent variables affect the banking businesses in the long run, then it cannot be expected that these parameters are statistically significant in the model where the dependent variable is short-term corporate loans.

In other words, GDP growth or its decline certainly affect corporate loans, but this effect is evident in the long run (e.g., 9, 12 or 16 months). Similarly, high inflation certainly does not benefit business entities in terms of their long-term 
plans, but in the short-term, inflation does not exert its influence. The reference interest rate should have, according to economic logic, statistical significance, because if a commercial bank borrows short-term funds from a central bank, then these short-term funds should be borrowed to commercial entities. However, failing to find the statistical significance of the reference interest rate in the model does not mean that it does not have an impact on short-term loans, but rather points to the imperfection of the model. That is, if another model or other methodology is applied, it would be very possible the reference interest rate would be statistically significant.

As for the exchange rate, the insignificance of this factor in the model means that the fluctuations of the exchange rate over the observed period are not strong enough to influence economic entities when deciding to use short-term loans. This assertion is in line with economic logic because these loans are used primarily to settle some short-term liabilities e.g., for suppliers or employees, to refinance previously borrowed items, etc. Euribor is statistically insignificant, because commercial banks generally do not borrow short-term funds in the European interbank market, but rather from the National Bank of Serbia. Therefore, it is expected that Euribor has no statistical significance.

In model for STLE, the coefficient of determination is the lowest compared to all other models and its value is $26 \%$. However, we have to say that such a low value of $R^{2}$ is expected, because according to the estimated model, none of the variables is statistically significant, that is, the selected macro factors do not have an effect on the dependent variable (STLE), which indicates that some other factors may have greater influence on STLE. Error terms of the model do not report the presence of autocorrelation, according to DW and BG tests.

\subsection{SHORT-TERM LOANS FOR POPULATION}

The last type of loans in our analysis are short-term loans granted to population (STLP). In this category we can distinguish between several types of banking products such as: arranged overdrafts, credit cards, cash loans, consumer loans (loans approved for the purchase of consumer goods, payment of tourist, health and other services). According to the results, two parameters are statistically significant - the reference interest rate and the Euribor. The statistical significance of the reference interest rate is very high and amounts to $99 \%$, while the significance of Euribor is also very high and amounts to $96 \%$.

The reference interest rate parameter has a value of -126 million, which means that the increase of $1 \%$ in the reference interest rate by the National Bank of Serbia results in a decrease in short-term loans towards population by 126 
million on average. This value is in accordance with economic logic, because any increase in the reference interest rate by the NBS directly impacts the rise in domestic loans to households, and this increase consequently affects the lower issuance of these loans by the bank. Unlike in the LTLP model, where the estimated Euribor parameter is -500 million, this parameter in STLP model is around -176 million, which means that an increase of $1 \%$ in Euribor affects long-term loans to population much more than short-term loans to population. This estimate is in line with expectations, because the sheer volume of longterm loans to households is larger than in the case of STLP.

Unlike Euribor and the reference interest rates, which are statistically significant in STLP model, all other variables are not statistically significant. In other words, a change in GDP does not affect the volume of short-term loans to households. According to the model, the change in GDP is not large enough to stimulate an increase in the volume of short-term loans to households. In addition, inflation and the exchange rate are also statistically insignificant. According to the model, this means that inflation in Serbia is not high enough to reduce STLP. It has been found that exchange rate is not statistically significant in STLP model, which is similar to all other previously estimated models. In particular, it means that the change in the RSD/EUR does not have any effect on the volume of short-term placements to households, because short-term loans to households are primarily issued in RSD. Therefore, we can contend that this macro factor does not have any influence on the demand for this type of credits.

According to diagnostic tests, the model is well specified, because $R^{2}$ coefficient indicates relatively high explanation power of $82 \%$, while DW and BG tests show that the model is not polluted by the serial correlation.

\section{CONCLUSION}

This paper examines how key macro-economic factors - GDP, inflation, referent interest rate, exchange rate changes and Euribor affect the volume of issued loans of Erste bank to civil population and enterprises in Serbia. We use several multivariate regression models to answer this question, and results are heterogeneous. Despite common opinion that macro factors influence bank business in one way or another, we find that not all fundamentals impact the bank credit activity. In particular, we report that Euribor is the most important factor, since it affects most of the bank products - LTLE, LTLP and STLP, where LTLE are hit the hardest. These results are well grounded, because Euribor is essential cost that the bank needs to bear in the process of financial fund procurement, and the level of this interest rate directly spills over to the interest rate of the bank credit to civil sector and enterprises. Due to the fact that long term loans to enterprises have the highest amount, the rise of Euribor affect 
these loans the strongest. Besides Euribor, we find that other macro fundamentals influence the volumes of the bank loans only sporadically. More specifically, the level of GDP and inflation affect only LTLE, while referent interest rate has an influence only on STLP. Interestingly, exchange rate changes have no effect on any loan of Erste bank, whatsoever, which clearly indicates that the bank protects itself very successfully against this type of macro risk.

According to the results, it seems that Euribor is the factor on which the bank needs to pay the highest attention. At the same time, bank can adjust its performance depending on this factor. In other words, due to the fact that Euribor has the strongest and the widest effect on the bank loans, it would be beneficial for Erste bank to keep track of global economic (and political) developments and forecast the future level of Euribor. In that regard, the bank could borrow higher amount of financial funds in times when Euribor is relatively low or records downward trends, and thus reduce costs of financial funds in times when the rise of Euribor is expected. Alternatively, the bank could make some type of interest rate hedging deal in global financial markets, protecting itself by borrowing the funds in times when global interest rates start to rise.

\section{REFERENCES}

Abuka, C., Alinda, R. K., Minoiu, C., Peydró, J-L., Andrea F., \& Presbitero, A. F. (2019). Monetary policy and bank lending in developing countries: Loan applications, rates, and real effects. Journal of Development Economics, 139, 185-202.

Baum, C. F., Caglayan, M., \& Ozkan, N. (2009). The second moments matter: the impact of macroeconomic uncertainty on the allocation of loanable funds. Economic Letters, 102(2), 87-89.

Busch, C. M., \& Prieto, E. (2014). Do better capitalized banks lend less? Long-run panel evidence from Germany. International Finance, 17(1), 1-23.

Caglayan, M., \& Xu, B. (2019). Inflation volatility effects on the allocation of bank loans. Journal of Financial Stability, 24, 27-39.

Chen, L., Pourahmadi, M., \& Maadooliat, M. (2014). Regularized multivariate regression models with skew-t error distributions. Journal of Statistical Planning and Inference, 149, 125-139. 
Den Haan, W. J., Sumner, S. W., \& Yamashiro, G. M. (2007). Banks' loan portfolio and the monetary transmission mechanism. Journal of Monetary Economics, 54(3), 904-924.

Glen, J., \& Mondragón-Vélez, C. (2011). Business cycle effects on commercial bank loan portfolio performance in developing economies. Review of Development Finance, 1, 150-165.

Gu, X., Xin, Y., \& Xu, L (2019). Expected stock price crash risk and bank loan pricing: Evidence from China's listed firms. Pacific-Basin Finance Journal, 57, 101-166.

Hasanov, F. J., Bayramli, N., \& Al-Musehel, N. (2018). Bank-specific and macroeconomic determinants of bank profitability: evidence from an oildependent economy. International Journal of Financial Studies, 6(3), 78.

Kamani, E. F. (2019). The effect of non-traditional banking activities on systemic risk: Does bank size matter? Finance Research Letters, 30, 297-305.

Lee, J-P., Lin, E. M. H., Lin, J. J., \& Zhao, Y. (2020). Bank systemic risk and CEO overconfidence. North American Journal of Economics and Finance, 54, 100946.

Lojanica, N., \& Tubić-Ćurčić, T. (2019). Economic growth and economic inequality in Visegrád countries: empirical analysis. School of Business, 2, 3551.

Mori, Y., \& Suzuki, T. (2018). Generalized ridge estimator and model selection criteria in multivariate linear regression. Journal of Multivariate Analysis, 165, 243-261.

Petrella, L., \& Raponi, V. (2019). Joint estimation of conditional quantiles in multivariate linear regression models with an application to financial distress. Journal of Multivariate Analysis 173, 70-84.

Ognjanović, J., \& Pešterac, A. (2019). Research on the relationship between intellectual capital and indicators of work results of employees in the banking sector of the republic of Serbia. School of Business, 2, 1-22.

Ongore, V. O. (2013). Determinants of Financial Performance of Commercial Banks in Kenya. International Journal of Economics and Financial Issues, 3(1), 237- 252.

Orzechowski, P. E. (2017). Bank profits, loan activity, and monetary policy: evidence from the FDIC's Historical Statistics on Banking. Review of Financial Economics, 33(2017) 55-63. 
54 | THE EFFECT OF MACRO FACTORS ON BANK CREDIT ACTIVITY IN THE REPUBLIC OF SERBIA

Otuori, O. H. (2013). Influence of exchange rate determinants on the performance of commercial banks in Kenya. European Journal of Management Sciences and Economics, 1(2), 86-98.

Xia, C., Zhang, A., Wang, H., \& Yeh, A. G. O. (2019). Predicting the expansion of urban boundary using space syntax and multivariate regression model. Habitat International, 86,126-134.

Živkov, D., Njegić, J., \& Ljumović, I. (2013). Linkage between external and internal imbalance: The case of Serbia. Industrija, 41(4), 127-142.

Delivered: 04.08.2020.

Accepted: 11.11.2020. 